\title{
OSTREA JACOBÆA.
}

CHARACTER GENERICUS.

Animal Tethys.

Testa bivalvis, inæquivalvis, subaurita.

Cardo edentulus fossula cava ovata striisque lateralibus transversis.

CHARACTER SPECIFICUS, छ̋C.

OSTREA JАCOBÆA. O. testa inæquivalvi radiis quatuordecim angulatis longitudinaliter striatis.

Gualt. test. t. 99. f. s.

Lesser testaccoth. f. 139 .

In oris Europæis sæpins reperitur Ostrea Jacobeea, coloribus non raro varians, Ostrea maxima, ut plurimum, paulo minor. 


\section{JACOBEAN SCALLOP.}

\section{$4 * 4 * 4 * 4 * 4 * * * 4 * 4 * 4 * 4 * 4 * 4 *$}

\section{GENERIC CHARACTER.}

Animal allied to a Tethys.

Shell bivalve : valves unequal, subauriculated. Hinge toothless, with an ovate fossule and transverse lateral streaks.

\section{SPECIFIC CHARACTER, छ้C.}

SCALLOP with fourteen angular, longitudinally-striped rays.

Lesser SCALLOP.

Penn. Brit. Zool. pl. 6o. f. 62.

The Jacobæan Scallop is sufficiently common about the European coasts, often varying in colour, and generally rather smaller than the common Scallop. 
639

640

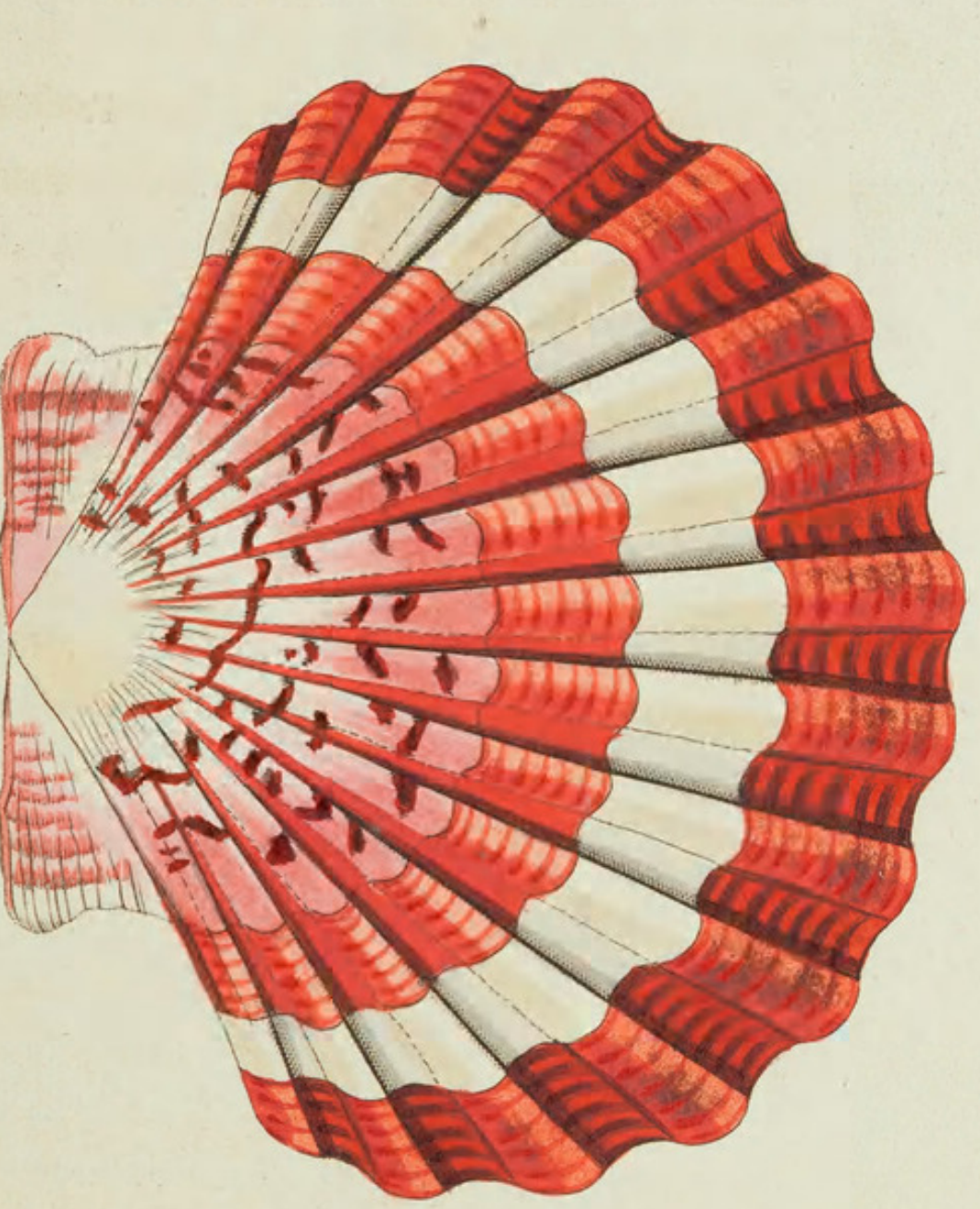

R.P. $\mathcal{D}_{\text {Delt }} \rho_{\text {culpt }}$. 


\section{$2 \mathrm{BHL}$ Biodiversity Heritage Library}

Shaw, George. 1804. "Jacobæan Scallop, Ostrea Jacobæa [PI. 639]." The Naturalist's Miscellany 16(CLXXXI), https://doi.org/10.5962/p.311080.

View This Item Online: https://www.biodiversitylibrary.org/item/281942

DOI: https://doi.org/10.5962/p.311080

Permalink: https://www.biodiversitylibrary.org/partpdf/311080

\section{Holding Institution}

Museums Victoria

\section{Sponsored by}

Atlas of Living Australia

\section{Copyright \& Reuse}

Copyright Status: Public domain. The BHL considers that this work is no longer under copyright protection.

This document was created from content at the Biodiversity Heritage Library, the world's largest open access digital library for biodiversity literature and archives. Visit BHL at https://www.biodiversitylibrary.org. 